\title{
REVOLUTIONARY READINGS: MARY SHELLEY'S FRANKENSTEIN AND THE LUDDITE UPRISINGS
}

Edith Gardner

He who fights with monsters might take care lest he thereby become a monster.

Nietzsche, Jenseits von Gut un Bose.

There are many possible and fascinating avenues of study in considering Mary Shelley's Frankenstein. The lasting popularity of the novel and the myths that have grown out of it are due in large part to the empty signifier of the Monster, into which many a critics' "ultimate concern" has been placed. The novel has been written about in terms of the themes of flight and pursuit, persecution and destruction; the importance of appearances; rationalism, emotionalism and perfectibility; the unconscious and insanity; fate, religion and nature; the anti-hero, rebel and outcast; promethean and faustian overreachers; alter-egos and doppelgangers; isolation; education; the characters' obsessions; imperialism and racism; personal and familial relationships; the role of women, society and the individual; Mary Shelley's own attitudes towards her parents, her husband, childbirth and motherhood.

I shall argue that Frankenstein can be read as a depiction of the contemporary situation in Britain in terms of the Luddite uprisings which occurred between 1811 and 1817 . There is no hard and fast evidence that this is how Mary Shelley intended her novel to be read, or that this was her main focus. But the similarities are striking enough, and an appreciation of this segment of history can enrich and illuminate our reading of the novel. Mary's journals and correspondence make references to the Luddites and to the all pervasive contem- 
porary fear of revolution. One such example occurs in a letter to Percy written from Marlow on 30 September 1816. Appalled by William Cobbett's incitement to revolution in his "twopenny trash," the cheap edition of his Political Register, Mary Shelley fears the outcome of his influence could be a bloody revolution:

Have you seen Cobbett's 23 No. to the Borough mongers-Why he appears to be making out a list for proscription-I actually shudder to read it - a revolution would not be bloodless if that man has any power in it ... he encourages in the multitude the worst possible human passion revenge or as he would probably give it that abominable Christian name retribution. (Bennett 49 )

Revenge and retribution are the passions that are to fuel both the Monster and his creator.

Frankenstein has already been interpreted as an allegory of the French Revolution and as a warning against violent revolution. David Ketterer asserts that "if the monster can be associated with unconscious ideas, it is but a small step to equate repressed levels of mind with the lower classes, the [French] revolutionary masses" (36). Franco Moretti views Frankenstein from a Marxist perspective, seeing in it "a pregnant metaphor for the process of capitalist production, which forms by deforming, civilizes by barbarizing, enriches by impoverishing" (87). The Monster, like the proletariat,

is a collective and artificial creature .. Reunited and brought back to life in the monster are the limbs of those-the 'poor'whom the breakdown of feudal relations has forced into brigandage, poverty and death ... Between Frankenstein and the monster there is an ambivalent, dialectical relationship, the same as that which, according to Marx, connects capital with wagelabour. (85)

Drawing on Moretti and Marx, Elsie Michie sees in the novel a story of production rather than creation, a "systematic attempt to deal with the issue of material production and the problems arising from it" (93). In her reading she posits Frankenstein as a figure who stands for the "alienation of the worker" distanced from the work he produces (94). Anne Mellor states that Frankenstein's act of creation can be seen

as an attempt to exploit nature or labor in the service of a ruling class... [Frankenstein's] project is identical with that of bourgeois capitalism: to exploit nature's resources for both commercial profit and political control. (112)

She equates Victor Frankenstein with the factory owner who gathers 
men to work his machines, as Frankenstein does pieces of dead bodies to fashion the Monster (112). These workers have the potential to become more powerful than their creators, which could in turn lead to

bloody revolutions in which the oppressed overthrow their masters ... Mary Shelley's tale of horror is ... a profound insight into the probable consequences of ... morally insensitive scientific and technological research. (114)

By the summer of 1816 , when Mary Shelley began writing her novel, the icon of the monster already carried with it political overtones. Lee Sterrenburg demonstrates how Mary could have picked up a way of seeing "the populace as monster" from the tropes of Conservative anti-Jacobin journalism which employed such images as graverobbing, reviving the dead, and monsters who turn on their creators and destroy them, to warn of the dangers of liberal reform (145). Sterrenburg sees Mary Shelley's Monster as

a very philosophical rebel. He explains his actions in traditional republican terms. He claims he has been driven to rebellion by the failures of the ruling orders. His superiors and protectors have shirked their responsibilities tow ards him, impelling him to insurrection. (161)

Very few critics have seen the novel as a response to the contemporary working class situation in Britain: Mellor and Sterrenburg refer to it very briefly. Paul O'Flinn is the only scholar to begin to do more than note this possibility in passing in his article entitled "Production and Reproduction: The Case of Frankenstein." He argues that

just as Frankenstein's creation drives him through exhausting and unstinting conflicts to his death, so too a class called into being by the bourgeoisie and yet rejected and frustrated by it will in the end turn on that class in fury and vengeance and destroy it. (199)

O'Flinn links the novel specifically to the Luddite disturbances. He points out that the cycle of "murders and reprisals" which characterized this period in British history, also characterize the action of the novel (200).

In my reading, Frankenstein represents the upper classes and the British government, while the Monster represents the lower, or working-class: the Luddites. Just as the government and the upper classes were terrified of a revolution by the working-class they had created, so Frankenstein is afraid that he will lose everything to the machinations of the Monster he has fashioned. The poor laborers and their 
advocates believed that the government had a duty to listen to its people, and to provide the basic necessities to which they have a right: food, clothing, shelter, employment, higher wages, lower prices, sympathy and philanthropy. Likewise Mary Shelley argues that Frankenstein, as creator, has certain responsibilities to his creation, and from him only can the Monster seek redress. Frankenstein owes him the same basic necessities the government owes its people; he also owes his progeny a name, affection, acceptance, and recognition as a sentient being with rights.

Just as Mary Shelley shows that kindness is the only way to make (or keep) the Monster good, so, I argue, she is saying that the only way to avert a bloody revolution is to treat the lower orders kindly. All men are born good, it is their treatment by society that can render them evil.

The years 1811 to 1817 were ones of severe deprivation for the new working class, a class created by what is generally termed the "Industrial Revolution". ${ }^{1}$ The Peninsular War of 1808-14, the War of 1812 and the Waterloo Campaign of 1815 , bad harvests, the astronomical price of corn, the influx of agricultural workers into industry, the large numbers of Irish immigrants, trading and manufacturing privations and losses due to the wars and the closure of the American market, the failure of banks and the collapse of exports, as well as the use of unemployment-causing machinery and low wages due to the manufacture of cheap goods, were all contributing factors to the national crisis faced by Britain during those years.

In 1812 witnesses for a parliamentary committee testified that the distresses of the working-class were the most severe they had ever encountered (Thomis 43). Such hardship inspired the Luddite revolts and other uprisings. Working men in villages and towns were claiming general rights for themselves, due in large part to the French and American Revolutions and to the writings of such radicals as Thomas Paine (The Rights of Man, 1791-2) and William Cobbett (Political Register).

Skilled craftsmen in the textile industries were being displaced by steam-and water-powered machines, as well as by cheap, unskilled labor and the production of second-rate goods. The remaining craftsmen were forced to move from their traditional work place of the home into inhospitable mills and factories. A new laboring-class and a new manufacturing bourgeoisie or middle class were being created.

The Luddite uprisings took place in three areas and had specific targets: the framework knitting hosiery and lace trade in Nottinghamshire, Leicestershire and Derbyshire; the shearing-gigs of the Yorkshire woollen industry; and the cotton industry in Lancashire and Cheshire where power looms were displacing hand-looms. The 
Luddite disturbances, with the exception of those in Yorkshire, were not directed at the machinery as such; the breaking of frames was a convenient and ready method of drawing attention to the sufferings of the laboring class. The machines that were displacing textile workers were not new. Machine breaking actually began in the seventeenth century (Hobsbawm 6) and was a recognized form of industrial action. The difference between the Luddites and earlier episodes of machine breaking lies in their intensity. Never had there been such wide-scale industrial disturbances. The Luddites eventually turned to rick- and stack-burning, to the destruction of property owned by their employers, and to bloodshed and murder.

An army of 12000 was called out to quell the disturbances-an army larger than Wellington had commanded in Portugal in 1808, and six times larger than any force previously directed against domestic unrest. In March 1812 machine-breaking was made a capital offence; the sentence had previously been fourteen years transportation.

The fears of revolution in Britain during this time were very real, and it was commonly believed that civil war was immanent. In November 1811 Nottingham magistrates stated that:

There is an outrageous spirit of tumult and riot, houses are broken into by armed men, many stocking-frames are destroyed, the lives of opposers are threatened, arms are seized, stacks are fired, and private property destroyed. (Felkin 45)

In December the Leeds Mercury proclaimed that "the Insurrectional state to which this county has been reduced for the last month has no parallel in history, since the troubled days of Charles the First" (Thompson 554). The Home Secretary and his local representatives were the recipients of many letters declaring the belief that the Luddites were planning a revolution, and that their design was to overthrow the government. A radical journalist in the Independent Whig of 27 July 1817 cautioned that "it is to a Revolution they will ultimately be compelled to resort, if all other legal means be denied of obtaining a Redress of Grievances" (Thompson 624).

Victor Frankenstein is similarly terrified by the destruction of which the Monster is capable. He is tortured by the thought of the "depraved wretch, whose delight was in carnage and misery ... endowed with the will and power to effect purposes of horror" (72). ${ }^{2}$ At first he refuses to create a mate for the Monster because he is afraid of the consequences to his world: "Shall I create another like yourself, whose joint wickedness might desolate the world ... you will then have a companion to aid you in the task of destruction" (141-3). Frankenstein's fears are selfish: he is terrified that the Monster will 
destroy everyone he loves, "there was always scope for fear, so long as anything I loved remained behind" (87).

Eric Hobsbawm recognizes that the need for employment among the British laborers and the ability to maintain a standard of living "included non-monetary factors such as freedom and dignity, as well as wages" (11). George Beaumont, the author of The Beggar's Complaint . . . Some Observations on the Conduct of the Luddites (1813), wishes to set the record straight because "though the poor may be challenged and accused even unjustly, with impunity, yet the rich will not be told the truth respecting their misconduct" (vi). Both they and Frankenstein need to be made aware of their duties. Calling the upper class a monster, Beaumont declares that they are "the parents of the indescribable sufferings" (19) of the lower classes: "Look at these things $\mathrm{O}$ proud monster Aristocracy! These scenes of distress are thy legitimate offspring" (21). Laying the blame squarely at their feet, he lambastes those in power for their refusal to address the real needs of the people, for employing punitive measures instead of providing food:

\footnotetext{
Now, say, ye Philanthropists, ye men of reason, candour, and humanity, is it just, is it equitable; first to drive men mad by oppression, and then hang them by group in a day for being mad? Is it equitable and christian-like in Judges and Juries, and Counsellors to make a mighty stir about the effects of oppression, and yet never utter a word about the cause of it? Is it right to give a man a halter who only wants a loaf? Pray, Sirs, where shall we learn that Hemp would make a good substitute for Bread? (112)
}

Both the Luddites and the Monster feel that they are being displaced from the positions they ought to hold and, in the case of the textile workers, had once held, in society. Thompson writes that "the bonds ... which bound them to the rest of the community in reciprocal obligations and duties, were being snapped one after another" (546). After the De Laceys desert their cottage, the Monster feels equally abandoned: "My protectors had broken the only link that held me to the world" (134). He asserts to Frankenstein that what he needs in order to feel once more connected with the world is communion with another: "I shall feel the affections of a sensitive being, and become linked to the chain of existence and events, from which I am now excluded" (143).

Many saw the primary cause of Luddism in the privations of the poor laborers. Manchester reformers were circulating handbills in April 1812 that spoke of "distress and wretchedness unexampled" (Bohstedt 159). Nottingham magistrates were reporting that it was the "calamitous privations of the poorer classes," the increasingly high 
price of provisions and the pressures of starvation that were responsible for the disturbances; harvest and trade needed to be addressed, not the issue of law and order (Thomis 44). "Could it in reason be expected, that those who are poor, hungry and dispirited, would manifest any violent predilection for a country which did not afford them the common necessaries of life?" asked Beaumont (98). One of the witnesses at the York Assizes in July 1812 affirmed that "If there was a good trade and meal come down, Ned Ludd will die" (Thomis 44).

Beaumont sees the origins of Luddism in the needs of the people and in the injustices perpetrated by the upper classes who refused to aid or even to listen:

The poor Mechanics . . . finding themselves hemmed in by multiplied oppressions of long duration, such as, War with all its attendant evils; Provisions high; Taxes high; Wages low; frequently work scarce; Law and Power nearly all on the side of the oppressors; no Public Writers to state the case of the Poor, in a just and impartial manner; News Printers, for the most part, either Knaves or Cowards, who had courage enough to libel and defame the Oppressed, but not virtue sufficient to defend them. What then, reader, was the consequence of all this? Why, LUDDISM! (110-111)

More than material provisions the Monster desires companionship, affection, love, sympathy, understanding, recognition: "Satan had his companions, fellow-devils, to admire and encourage him; but I am solitary and detested" (126). Desperate for companionship, the Monster ponders Adam's request of his Creator: "but where was mine? he had abandoned me, and, in the bitterness of my heart, I cursed him" (127). From the De Laceys he hopes for "compassion and friendship" (126), yet everywhere he meets with rejection. Disowned by his own father/creator, he finds no sympathy, no welcome, no understanding from others (with the exception of the blind De Lacey). He is chased, shot at, stoned, and run away from. Nowhere can he find solace, acceptance, companionship, human warmth, love and care. It is the denial of these basic rights, by society at large as well as by his creator, that drives the Monster to despair and consequently to revenge, hatred and destruction:

All, save I, were at rest or in enjoyment: I, like the arch fiend, bore a hell within me; and, finding myself unsympathised with, wished to tear up the trees, spread havoc and destruction around me, and then to have sat down and enjoyed the ruin ... from that moment I declared everlasting war against the species, and more than all, against him who had formed me, and sent me forth to this insupportable misery. (132-3) 
Just as Luddism would cease were the needs of the poor laborers met, so Frankenstein has the power to change the Monster's behavior should he so choose:

Make me happy and I shall again be virtuous . . . but am I not alone, miserably alone? ... Shall I not then hate them who abhor me? ... Yet it is in your power to recompense me . . . On you it rests whether I . . lead a harmless life, or become the scourge of your fellow-creatures, and the author of your speedy ruin.

(95-6)

Shall I respect man, when he contemns me? Let him live with me in the interchange of kindness, and, instead of injury, I would bestow every benefit upon him with tears of gratitude at his acceptance. (141)

Unadulterated misery makes it impossible to tell right from wrong: "You have made me wretched beyond expression," Frankenstein tells his creation, "You have left me no power to consider whether I am just to you, or not" (96). Unfortunately Frankenstein lacks the empathy, maturity, or simply the equanimity, to realize that if his own judgement is clouded by distress, then the distress suffered by the Monster could account for and occasion his destructive behavior. The Monster tries to point this out to Frankenstein: "I intended to reason. This passion is detrimental to me; for you do not reflect that you are the cause of its excess" (141). In a similar vein, George Beaumont declared that "multifarious and long continued oppressions will ultimately make men deaf to the dictates of reason, and prompt them to seek relief in acts of violence and desperation" (112).

Having assumed the role of creator, Victor Frankenstein owes certain things to his creature: the basic necessities of life with a good dose of philanthropy thrown in. These responsibilities go hand in hand with the power to create, as the Monster points out: "I am thy creature, and I will be even mild and docile to my natural lord and king, if thou wilt also perform thy part, the which thou owest me" (95). Mary has the Monster repeatedly compare himself unfavorably to Adam, both created beings. The Monster has been abandoned by the one person who should be taking care of him:

beings but with such different fates: Like Adam, I was created apparently united by no link to any other being in existence; but his state was far different from mine in every other respect. He had come forth from the hands of God a perfect creature, happy and prosperous, guarded by the especial care of his Creator... but I was wretched, helpless, and alone. (125) 
Like Adam, the Monster envisions someone to share his solitude. Unlike Adam, his "father" is not around to ask: "I remembered Adam's supplication to his Creator; but where was mine? he had abandoned me, and, in the bitterness of my heart, I cursed him" (127).

Unable to find Frankenstein, the Monster turns to the blind De Lacey with the basic requests his maker should have fulfilled: "I asked, it is true, for greater treasures than a little food or rest; I required kindness and sympathy" (128). Interrupted and attacked by Felix, the Monster's pain turns to anger against Frankenstein:

you were my father, my creator; and to whom could I apply with more fitness than to him who had given me life? .. . From you only could I hope for succor, although towards you I felt no sentiment but that of hatred ... on you only had I any claim for pity and redress, and from you I determined to seek the justice which I vainly attempted to gain from any other being that wore human form. (135-6)

The next day he sets off to find Victor. In their first verbal encounter, the Monster explains this notion of responsibility to Frankenstein, who seems to have no concept of it:

Oh, Frankenstein, be not equitable to every other, and trample upon me alone, to whom thy justice, and even thy clemency and affection, is most due. Remember, I am thy creature: I ought to be thy Adam; but I am rather the fallen angel, whom thy drivest from joy for no misdeed. Everywhere I see bliss, from which I alone am irrevocably excluded. (95)

When Victor tells him in no uncertain terms that he is wasting his time pleading his cause, the Monster replies that he can hope for nothing from anyone else if he cannot succeed with Victor:

How can I move thee? Will no entreaties cause thee to turn a favourable eye upon thy creature, who implores thy goodness and compassion . . . You, my creator, abhor me; what hope can I gather from your fellow-creatures, who owe me nothing?

The Home Secretary received numerous petitions and letters from the Luddites, complaining of low wages and high prices, and warning of the dreadful consequences if no remedies were forthcoming. Parliament was besieged with petitions and reasoned pleadings for their requests to be heard and granted. Since 1810 "petition after petition was sent to Parliament without the slightest hint of support from the parliamentary elite or any kind of ameliorative action" (Calhoun 62). By May 1812 the Prince Regent and his personal 
secretary were receiving numerous threatening letters. One, signed "Vox Populi," stated "Provisions Cheaper-Bread or Blood-Tell your Master he is a Damn'd Unfeeling Scoundrel."3

Similarly, the Monster begs Frankenstein to hear him:

I entreat you to hear me... Let your compassion be moved, and do not disdain me ... Listen to my tale ... But hear me ... Listen to me... listen to me .. . listen to me, and grant me thy compassion. Have I not suffered enough, that you seek to increase my misery? . . How can I move thee? Will no entreaties cause thee to turn a favourable eye upon thy creature, who implores thy goodness and compassion? (95-6)

His pleas become more fervent the longer he is kept waiting for an answer: "Oh, my creator, make me happy; let me feel gratitude towards you for one benefit! Let me see that I excite the sympathy of some existing thing; do not deny me my request!" (142). When Frankenstein refuses the Monster's rightful request for a companion, the Monster explains that there is nothing which will now keep him from evil:

I thought I had moved your compassion, and yet you still refuse to bestow on me the only benefit that can soften my heart, and render me harmless. If I have no ties and no affections, hatred and vice must be my portion. (143)

Both the Luddites and the Monster warn their victims before their attacks. Records of the Luddite trials at the York Assizes of January 1813 state that William Cartwright had received "previous notice" of the planned attack on his Rawfolds Mill. On 20 April 1812 a letter signed by "General Justice" was sent to the owner of improved cloth-dressing machinery stating that if he did not remove the offending frames within a week, his factory would be burnt. Other letters contained similar, but more violent, warnings: if frames are not removed they will be attacked, buildings will be burned and, should the employer resist, he will be murdered and his house set on fire. Thomas Latham wrote to the Mayor of Tewkesbury in March 1812 cautioning him that people "may be driven to the commission of crime when they cannot exercise their rights" (Thompson 536). George Beaumont records that "the Weavers seeing no prospect of any help from others, began now to think of helping themselves" (109). The Monster issues warnings to Frankenstein similar to those of the Luddites:

Do your duty towards me, and I will do mine towards you and the rest of mankind ... if you refuse I will glut the maw of death, until 
mine shall not be the submission of abject slavery. I will revenge my injuries: if I cannot inspire love, I will cause fear; and chiefly towards you my arch-enemy, because my creator, do I swear inextinguishable hatred. Have a care: I will work at your destruction, nor finish until I desolate your heart, so that you curse the hour of your birth. (141)

After the De Laceys flee in terror from the Monster and abandon their cottage, the Monster's pain and despair turn to anger:

For the first time feelings of revenge and hatred filled my bosom...allowing myself to be borne away by the stream, I bent my mind towards injury and death. When I reflected that they had spurned and deserted me, anger returned, a rage of anger. (134)

His anger turns to violence and that night, in an act familiar to the Luddites, he sets fire to the cottage:

I lighted the dry branch of a tree, and danced with fury around the devoted cottage ... with a loud scream I fired the straw, and heath, and bushes which I had collected. The wind fanned the fire, and the cottage was quickly enveloped by the flames, which clung to it, and licked it with their forked and destroying tongues. (135)

Having murdered William by mistake (grasping his throat to silence him), the Monster realizes his own power over his oppressor:

I gazed on my victim, and my heart swelled with exultation and hellish triumph: clapping my hands, I exclaimed, 'I, too, can create desolation; my enemy is not impregnable; this death will carry despair to him, and a thousand other miseries shall torment and destroy him.' (139)

On seeing Frankenstein destroy the female companion he was in the process of creating, the Monster swears eternal vengeance. The time for talking is over, for it has been of no avail:

Slave, I before reasoned with you, but you have proved yourself unworthy of my condescension. Remember that I have power; you believe yourself miserable, but I can make you so wretched that the light of day will be hateful to you. You are my creator, but I am your master; - obey! . . I had feelings of affection, they were requited by detestation and scorn. Man, you may hate; but beware! Your hours will pass in dread and misery ... Are you to be happy, while I grovel in the intensity of my wretchedness? . . . Man, you shall repent of the injuries you inflict. (165) 
The government, like Frankenstein, remained fundamentally unrepentant and opposed to reform. Petition after petition was ignored. Frame-breaking in Nottingham and the surrounding counties began in March 1811, but it was not until November that the Times was according it regular attention (Calhoun 69). The subject did not come before Parliament until February 1812, once the worst of the Nottinghamshire disturbances were over. The House of Commons awarded very little time to the issue, which received small audiences (Thomis 145). Unparalleled distress was falling on deaf ears.

When Malcolm Thomis writes of the failings of those in power to ameliorate the Luddite situation, he could be describing Frankenstein's failings in his response to the Monster. Both are racked with fear, inaction, lack of judgement and clarity, and an overwhelming egoism which thinks that it alone is the subject of all the anger and vengeance of the Luddite attacks or the Monster's warnings:

\begin{abstract}
Unfortunately the high qualities and initiative which the successful pursuit of the Luddites demanded were not markedly present inside the magisterial group; it was distinguished by its incompetence and misjudgments ... In part their weakness was an inability to judge the situation accurately; in part it appears to have been a question of fear or even cowardice ... Each thought his own area in the greatest danger of attack. (147-8)
\end{abstract}

Frankenstein is likewise paralysed, unable to decide on a plan of action, or to rouse himself from his all-engrossing, dead-end patterns of thought. He spends hours by himself brooding, or whole days drifting on Lake Geneva in a boat, overcome with inertia. He has a tendency to faint or to become ill and delirious when faced with the Monster. While he wants to safeguard what he has (like the British upper class), Frankenstein is totally ineffectual in dealing with the realities of the situation. His fears overwhelm him, and while he broods, or tries to forget, the Monster, like the British working-class, continues to agitate and to seek recompense for his distress. Frankenstein is convinced that the Monster's warning for him to beware on his wedding night means that it is he, not Elizabeth, who will be attacked (166). He draws no connection between the occasion of the Monster's utterance-the night Frankenstein destroys the Monster's half-finished mate-and a wedding night, a mating, a union with another, for which the Monster longs and from which he is forever excluded. Victor draws no parallel between his destruction of the Monster's "wife-to-be," and the fate of his own bride.

Beaumont describes behavior common to both the government and Frankenstein. Both justify their abdication of their responsibili- 
ties by positing their dependents as wicked and evil and therefore as undeserving of anything but punishment:

on the part of the Oppressors, it is their frequent practice to make out a justification of their conduct by libelling human nature, and saying that mankind are so ill-disposed by their very nature, that nothing but Whips, Gibbets, and Dragoons, can keep them in order! (118)

The government might have said with Frankenstein "I feel myself justified in desiring the death of my adversary. During these last days I have been occupied in examining my past conduct; nor do I find it blameable" (214). Reviewing his conduct towards the Monster on his deathbed, Frankenstein tells Walton: "I refused, and I did right in refusing, to create a companion for the first creature. He shewed unparalleled malignity and selfishness, in evil" (214-5).

George Beaumont is a firm believer in the innate goodness of man's soul, which the government has the power to foster or to destroy:

\footnotetext{
every nation is good or bad, as it is well or ill governed! In a word, when a nation becomes so vicious, that it is necessary to hang great numbers of people, in order to keep the rest in subjection, it is a sure evidence that the Rulers of that nation have forfeited all claim to veneration and confidence! (103)
}

At the end of his pamphlet, he quotes from St. Pierre: "Man is born good. It is Society that renders him wicked!" (124). Beaumont testifies to the good character of the Luddites even under severe conditions:

The patience of the Weavers under these severe privations, was worthy of admiration. Disinclination to turbulence, and expectation of better times, induced many to hold their patience until they lost their lives, and when they had done, but few rich people cared a straw for them. The Weavers moreover shewed their unwillingness to disturb the public tranquility, by peaceably sending two Delegates to Government, in order to represent their distressed situations. (106)

Similarly Lord Fitzwilliam was convinced that if the laborers were put back to work, "outrage and conspiracy would die away, for they were assuredly the offspring of distress and unemployment" (Thomis 46). The Monster explains that he was born good, with an innate love of virtue: "I was benevolent; my soul glowed with love and humanity...I was benevolent and good" (95). His first reaction on discovering his maker, another animate being, is to smile (53). He takes pleasure in 
the sight of the rising moon, in bird song, in the music emanating from the De Lacey's cottage, in their mutual affection. While reading Plutarch's Lives, the Monster feels "the greatest ardour for virtue rise within me, and abhorrence for vice" (125). He has social and philanthropic intentions, desiring to befriend the De Lacey family, and secretly helping them by gathering their firewood. He later saves a girl from drowning, and attempts to establish a relationship with William Frankenstein, whom he earnestly hopes is young enough not to be ruled by prejudice.

It is hardship, despair and constant rejection that render him evil: "misery made me a fiend" (95), "I am malicious because I am miserable" (141). His loneliness and his frustrated search for sympathy, for friendship with a human being, are the cause of his misdeeds: "my vices are the children of a forced solitude that I abhor; and my virtues will necessarily arise when I live in communion with an equal" (143). The Monster promises Frankenstein that he will be good if he has but one living being with whom to interact: "My evil passions will have fled, for I shall have met with sympathy; my life will flow quietly away, and, in my dying moments, I shall not curse my creator . . the love of another will destroy the cause of my crimes" (143). If man would only live with him "in the interchange of kindness ... I would bestow every benefit upon him with tears of gratitude at his acceptance" (141).

Until Frankenstein destroys his mate, the Monster never fully relinquishes his better feelings. He burns the De Lacey's cottage because, "unable to injure anything human, I turned my fury towards inanimate objects" (134). Having burned it down, the Monster recounts that "the mildness of my nature had fled, and all within me was turned to gall and bitterness" (136). Yet but a few minutes later, the beauty of nature rouses within him

emotions of gentleness and pleasure, that had long appeared dead ... Half surprised by the novelty of these sensations, I allowed myself to be borne away by them; and, forgetting my solitude and deformity, dared to be happy. (137)

On beholding Frankenstein's corpse, the Monster explains to Walton that evil is neither a simple nor a painless choice for a soul that was endowed with the desire to be good:

My heart was fashioned to be susceptible of love and sympathy; and, when wrenched by misery to vice and hatred, it did not endure the violence of the change without torture, such as you cannot even imagine. (217)

He becomes a monster because of his contacts with society; he 
becomes, painfully, the evil creature society had always assumed him to be. Society and Frankenstein create the monster within the Monster. The fact that an innately good soul should become evil through its contacts with society is a reflection, and a damning one, on that society. Beaumont agreed with Mary Shelley: "It is an ill symptom of the state of mankind, when men become insensible to the sufferings of their fellow creatures" (19).

Arms thefts by the Luddites, and the use of weapons against their opponents, did not begin until they themselves had been the victims of physical violence. William Cartwright had drawn the first blood by shooting two Luddites during the attack on his Rawfolds Mill on 11 April 1812. The Luddites threatened that violence would continue until their demands were met:

\begin{abstract}
We will never lay down Arms [till] The House of Commons passes an Act to put down all Machinery hurtful to Commonality, and repeal that to hang Frame Breakers. But We. We petition no more-that won't do-fighting must. (Thompson 560)
\end{abstract}

The Monster does not take human life until he has also been wounded by gunfire. Mistaken for attempting to abduct a girl when he has actually saved her from drowning, he is shot by her male companion (137). Such personal violence has a profound effect upon him:

The feelings of kindness and gentleness, which I had entertained ... gave place to hellish rage and gnashing of teeth. Inflamed by pain, I vowed eternal hatred and vengeance to all mankind. (138)

It is but days later that he murders William Frankenstein. Five more deaths, including Frankenstein's, will be attributed to him before the end of the novel.

Neither the Luddites nor the Monster destroyed property or human lives indiscriminately. Their targets were deliberately chosen. The Luddites selected for their attacks those objects which would most affect their employers: machinery, raw material, finished goods, or private property. Their assassination attempts were perpetrated against factory or mill owners who employed the "wrong" type of machinery, underpaid their workers, or hired cut-rate laborers. In December 1811, the Leeds Mercury was writing that the Luddites "broke only the frames of such as have reduced the price of men's wages; those who have not lowered the price, have their frames untouched" (Thompson 685). "Luddites had a reputation as respecters of private property outside of the machinery and materials that were harmful to their livelihood" (Thomis 108). 
The Monster steals food only when he can bear his hunger no longer (102). The Monster's victims are only those connected to the Frankenstein household. He destroys the De Lacey's cottage because of their abandonment of him, but he does not destroy other property, nor does he threaten the lives of other human beings, although they shoot at him, stone him, attack him with a stick, and flee him.

Through the Monster and Frankenstein's destructive relationship, Mary Shelley adds a warning, not just of the consequence of abdicating one's responsibility towards one's fellow man, but of the inherent cost to both parties of such behavior. Destruction takes its toll not only on the victims of that destruction, but also on its perpetrators. George Beaumont is one of the few contemporaries to see this; he attests to the fact that "both the Oppressors and Oppressed are spoiled in their sentiment and moral feeling" (118). Violence begets the desire for vengeance, vengeance for violence, in a cycle that has no end but in death. Baron Thompson, in pronouncing the death sentence upon those involved in the murder of William Horsfall and the attack on Cartwright's mill, stated that the men were being hanged as a warning to others of the impossibility of turning back from the path of violence and destruction. One of the convicted, William Thorpe, said from the gallows: "I hope none of those who are now before me will ever come to this place" (Peel 219).

Frankenstein's feelings of hatred against the Monster are as strong as the Monster's against him; they both desire the destruction of the other. After William's death and Justine's execution, Frankenstein exclaims:

My abhorrence of this fiend cannot be conceived... I gnashed my teeth, my eyes became inflamed, and I ardently wished to extinguish that life which I had so thoughtlessly bestowed. When I reflected on his crimes and malice, my hatred and revenge burst all bounds of moderation . . . I wished to see him again, that I might wreak the utmost extent of anger on his head, and avenge the deaths of William and Justine. (87)

Frankenstein's fury is as unbounded as the Monster's though, we may feel, much less justified:

Devil! . . . do you dare approach me? and do not you fear the fierce vengeance of my arm wreaked on your miserable head? Begone, vile insect! or rather stay, that I may trample you to dust! ... Abhorred monster! fiend that thou art! the tortures of hell are too mild a vengeance for thy crimes. (94)

The words "anger," "hatred," "revenge," and "vengeance" occur 
numerous times in the novel. The Monster and Frankenstein are caught in a cycle of revenge and retribution that will end only in the death of one of them:

you, my creator, detest and spurn me, thy creature, to whom thou art bound by ties only dissoluable by the annihilation of one of us. (the Monster, 94)

You can blast my other passions, but revenge remains-revenge, henceforth dearer than light or food! I may die; but first you, my tyrant and tormentor, shall curse the sun that gazes on your misery. (the Monster, 165)

Again do I vow vengeance; again do I devote thee, miserable fiend, to torture and death. Never will I omit my search, until he or I perish. (Frankenstein, 202)

Prepare! your toils only begin ... your sufferings will satisfy my everlasting hatred. (the Monster, 203)

Through the Monster's lamentations over Frankenstein's corpse Mary Shelley warns that remorse and regret will come to all locked in such a battle. The Monster cannot believe that he was once a being who aspired to be good:

Vice has degraded me beneath the meanest animal. No crime, no mischief, no malignity, no misery, can be found comparable to mine. When I call over the frightful catalogue of my deeds, I cannot believe that I am he whose thoughts were once filled with sublime and transcendent visions of beauty and the majesty of goodness. (219)

Uttering "wild and incoherent reproaches" (217), the Monster tells Walton that vengeance brings no ultimate satisfaction, although he once thought that it would when he entertained "a deep and deadly revenge, such as would alone compensate for the outrages and anguish I had endured" (138); "whilst I destroyed his hopes, I did not satisfy my own desires. They were forever ardent and craving" (219). He is now filled with self-loathing:

Once my fancy was soothed with dreams of virtue, of fame, of enjoyment ... But now vice has degraded me beneath the meanest animal ... You hate me; but your abhorrence cannot equal that with which I regard myself. (219)

The only end to his agony is death, for then "I shall no longer feel the agonies which now consume me, or be the prey of feelings unsatisfied, 
yet unquenched" (220). The passions of revenge and destruction, once indulged in, become all-consuming: "impotent envy and bitter indignation filled me with an insatiable thirst for vengeance" (218). Willingly or unwillingly, one becomes their slave while still not immune to better feelings:

do you think that I was then dead to agony and remorse? . . he suffered not more in the consummation of the deed;-oh! not the ten-thousandth portion of the anguish that was mine during the lingering detail of its execution. (217)

The Monster describes the anguished process of such a transformation upon the soul:

A frightful selfishness hurried me on, while my heart was poisoned with remorse ... I abhorred myself ... I was the slave, not the master of an impulse, which I detested, yet could not disobey. . . Urged thus far, I had no choice but to adapt my nature to an element which I had willingly chosen. The completion of my demoniacal design became an insatiable passion ... the fallen angel becomes a malignant devil. (218-9)

In my reading, Frankenstein warns of the outcome of neglect and abuse, of the shirking of responsibilities. They are the cause of the Monster's evil. That mistreatment produces the Monster's malevolence was understood by Mary Shelley's contemporaries. The reviewer for Blackwood's Edinburgh Magazine, for example, stated that "this monster ... becomes ferocious and malignant, in consequence of finding all his approaches to society repelled with injurious violence and offensive marks of disgust" (618). Percy Shelley regarded this as the most important point that Mary's novel had to make. In a posthumously published review he stated:

Nor are the crimes and malevolence of the single Being ... the offspring of any unaccountable propensity to evil, but flow irresistibly from certain causes fully adequate to their production. They are the children... of Necessity and Human nature. In this the direct moral of the book consists ... Treat a person ill and he will become wicked. Requite affection with scorn; let one being be selected for whatever cause as the refuse of his kind-divide him, a social being, from society, and you impose upon him the irresistible obligations-malevolence and selfishness. (Clark 107 8)

Just as the Monster was born good, with aspirations of virtue and benevolence, so the Luddites were ordinary, good-hearted men. Both the Luddites and the Monster begin by trying to petition their masters 
for better treatmert. As the government consistently ignored the peaceful measures of the Luddites, so Frankenstein refuses to listen to the Monster's eloquent pleas: "For it is not the way in modern times, to redress grievances and remove oppressions; but rather to stifle complaints, and suppress remonstrances by Dragoons, Prisons, Gibbets, and Foul Names!" (Beaumont 109). When the petitions fail, the Monster and the Luddites issue warnings, and when these warnings are ignored, they are forced to take action. Both the Luddites and the Monster illustrate the fact that "there is a point beyond which human nature cannot bear." 4 They turn to the use of violence against property and, once they have been attacked with fire arms, to bloodshed.

The attacks by the Monster and the Luddites remain specific and focused, but driven too far, the ultimate consequence will be bloody rebellion. Larger and stronger than their makers, the Monster and the Luddites have the power to wreak a terrible revenge upon their oppressors. Luddism was so frightening because of its efficiency and its potential: "Luddism involved the systematic use of organised and controlled violence for the achievement of its aims...as if violence were a legitimate and usable weapon that could be invoked as and when necessary by the working classes" (Thomis and Holt 34). Similarly the Monster warns Frankenstein, "Beware, for I am fearless, and therefore powerful" (165). It is at this point that Mary Shelley offers her own critique of the situation: the cycle of revenge and retribution, once begun, cannot end but in the death of one or both of the opponents; the agonies of bitter remorse and regret will be the lot of all who participate in such a battle. This belief was shared by a few of the contemporary recorders of the highly charged situation in Britain: "Oppression is a consummate evil, inasmuch as it induces ferocity, misanthropy, disaffection between man and man, ignorance and cruelty; by it both the Oppressors and Oppressed are spoiled in their sentiment and moral feeling" (Beaumont 118).

Mary Shelley traces the steps which lead from innate goodness to hatred, anger and the desire for revenge. Her achievement in depicting this journey is perhaps brought into sharper relief when we read a statement such as the one made by Thomis and Holt: "The making of rebels from men of good character and peaceable disposition is a process that cannot be described and can only be inferred" (55). Thomis goes on to assert that

it was left to the critics of the government to suggest that an equal concern should be the matters which gave rise to Luddism and that a more constructive approach to the problem might be to investigate the causes with a view to eliminating them, rather than simply to deal with the outward manifestations of the discontent. (Luddites 32) 
This Mary does. She also proffers a solution: philanthropy. If every one accepted their responsibilities and treated everyone else with kindness and sympathy, mankind would be content. Mary Shelley was ahead of her time in suggesting that in philanthropy and sympathy lay the answer to industrial unrest; Ellis points out that "to say that domestic affection, extended to the public sphere, is an inadequate remedy for the ills of an industrial society would be to fly in the face of an idea that gained immense popularity in the Victorian era" (131). Mary Shelley's answer does not entail the restructuring of society, the elimination of the class system; it does entail a revolution of the human spirit and of the emotions which will issue in benevolent action towards one's fellow human beings, and in so doing, creating a better society whilst alleviating present ills.

\section{Notes}

${ }^{1}$ While not wishing to deny the legitimate debate over the validity of the term "the Industrial Revolution," I have chosen to use it here to describe a period of increased and concentrated industrialization, beginning at the end of the eighteenth century, but not really being felt and taken note of until the early decades of the nineteenth.

${ }^{2}$ All quotations are taken from Mary Shelley's Frankenstein or The Modern Prometheus: the 1818 Text. Ed. James Reiger.

${ }^{3}$ H. O. 42.123., qtd. Thompson 571 .

${ }^{4}$ Letter to the Home Secretary from Manchester, February 1812; qtd. in Thomis $1970,47$.

\section{Works Cited}

Beaumont, George. The Beggars Complaint. Sheffield: Crome 1812.

Bennett, Betty T. Ed. The Letters of Mary Wollstonecraft Shelley.

Baltimore and London: Johns Hopkins UP, 1980.

Bohstedt, John. Riots and Community Politics in England and Wales 17901810. Cambridge, MA; London: Harvard UP, 1983.

Calhoun, Craig. The Question of Class Struggle: Social Foundations of Popular Radicalism During the Industrial Revolution. Chicago: U of Chicago P, 1982. 
Clark, David Lee. Shelley's Prose or The Trumpet of a Prophecy. Albuquerque: U of new Mexico P, 1954.

Felkin, William. History of the Machine-Wrought Hosiery and Lace Manufactures. Cent. ed. Newton Abbot: David \& Charles, 1967.

Hobsbawm, E. J. Labouring Men: Studies in the History of Labour. 6th ed. London: Weidenfeld and Nicolson, 1964, 1979.

Ketterer, David. Frankenstein's Creation: The Book, The Monster, and Human Reality. English Literary Studies 16, U of Victoria, 1979.

Mellor, Anne K. Mary Shelley, Her Life, Her Fiction, Her Monsters. New York, London: Routledge, 1989.

Michie, Elsie B. "Frankenstein and Marx's Theory of Alienated Labor" in Approaches to Teaching Shelley's Frankenstein. Ed. Stephen Behrendt. Approaches to Teaching World Literature. New York: MLA, 1990.

Moretti, Franco. Signs Taken for Wonders, Essays in the Sociology of Literary Forms. Trans. Susan Fisher, David Forgacs and David Miller. Rev. ed. London, New York: Verso, 1988.

O'Flinn, Paul. "Production and Reproduction: The Case of Frankenstein" in Literature and History 9:2 (1983) 194-213.

Peel, Frank. The Risings of the Luddites, Chartists and Plug-Drawers. 1880. 4th ed. London: Frank Cass and Co., Ltd., 1968.

Quarterly Review (January 1818) 379-385.

Shelley, Mary. Frankenstein, or The Modern Prometheus: the 1818 Text. Ed. James Reiger. Chicago and London: U of Chicago P, 1974, 1982.

Sterrenburg, Lee. "Mary Shelley's Monster: Politics and Psyche in Frankenstein" in The Endurance of Frankenstein: Essays on Mary Shelley's Novel. Berkeley, L.A., London: U of California P, 1979.

Thomis, Malcolm I. The Luddites, Machine-Breaking in Regency England. Library of Textile History. Newton Abbot: David \& Charles; Hamden, CT: Archon Books, 1970.

Thomis, Malcolm I. and Peter Holt. Threats of Revolution in Britain 1789.

1848. London: Macmillan; Hamden CT: Shoe String Press-Archon Books, 1977.

Thompson, E. P. The Making of the English Working Class. New York: Pantheon Books-Random, 1963. 
